\title{
Unto Mononen, Olavi Virta ja tango Suomen kansan valittuina
}

Peter von Bagh toteaa Olavi Virta -elämänkerrassa: ${ }^{1}$ "Virran romahduksen ja kuoleman jälkeen musiikin tulkinnan suunta ikäänkuin kääntyi ympäri. Laulut alettiin kokea ja ymmärtää pelkästään Virran traagisten elämänvaiheiden kautta." Von Baghin huomio vie meidät mielenkiintoisen ongelman äärelle: kuinka iskelmälaulaja muuttuu elämää suuremmaksi? On olemassa joukko suomalaiskansallisen iskelmämusiikin piiriin kuuluvia esiintyviä taiteilijoita ja säveltäjiä, jotka ovat kanonisoituneet kyseisen musiikin osa-alueen historian pyhimmäksi ytimeksi, ja koko suomalaiskansallisen kulttuurin merkkihenkilöiksi. Tämän joukkueen ykkösketjuun kuuluvat itseoikeutetusti Olavi Virta sekä Unto Mononen. Kummallekin artistille on ollut yhteistä se, että heidän taiteensa on koettu ilmentävän jollakin tavalla erityisen syvällisesti suomalaista sielunmaisemaa. He kumpikin ovat olleet tavattoman suosittuja, sekä uransa aikana että myöskin kuolemansa jälkeen, erotuksena populaarimusiikissa yleensä vallalla olevaan tendenssiin, kulloinkin pinnalla olevien artistien jatkuvaan vaihtumiseen ja unohduksiin painumiseen. Yhtäläisyyksistä mielenkiintoinen on myöskin seuraava: kummankin elämää, varsinkin loppuaikoina, varjosti synkkä ja romanttinen tuhon uhka, rappiolla flirttailu ja yleinen itsetuhoinen käytös. Kumpikin romahti lopulta näyttävästi viinaan.

\section{Isä, poika ja pyhä henki}

Tässä artikkelissa keskityn seuraavaan teemaan: Olavi Virran, Unto Monosen ja tangon myyttiseen kolmiyhteyteen. Millä perustelen näiden kolmen entiteetin erikoislaadun, kahden ensimmäisen kaikkien Suomen viihdeammattilaisten ja viimeisen Suomen iskelmämusiikin pirtaan kuuluvien tanssirytmien joukossa? Valintani tuskin aiheuttavat kenessäkään lukijassa hämmästystä, vaan ehkä tuntuvat luonnollisuudessaan jopa triviaaleilta. On hedelmällistä miettiä niiden erityislaatua. Miksi ne tuntuivat luonnollisilta valinnoilta esimerkeiksi suomalaisen populaarimusiikin myyttisistä rakenteista? Ensimmäinen teesini on tämä: kansa tarvitsee myyttiset sankarihahmonsa, ja nämä hahmot kansa valitsee olemassa

\footnotetext{
${ }^{1}$ Von Bagh, Koski \& Aarnio: Olavi Virta - legenda jo eläessään.
} 
olevien vaihtoehtojen joukosta. Pisteitä näissä vaaleissa annetaan sen mukaan, kuinka hyvin tietyt ehdot täyttyvät.

\section{Ensimmäinen ehto: kansansuosio}

Ensimmäinen ehto on suosio. Olavi Virta oli 50-luvun suosituin suomalainen iskelmälaulaja. Levymyynti ei hänen kohdallaan ole vieläkään tyrehtynyt - kuluneella vuosikymmenellä hänen kaikki levyttämänsä kappaleet on julkaistu yhtenäisenä sarjana. Tango oli 60-luvun puolessa välissä kevyen musiikin lajeista ylivoimaisesti suosituin, monien aikalaisten mielissä rasittavuuteen asti. Tangosäveltäjistä suosituimpia, jonkin aikaa suosituin oli Unto Mononen. Se seikka, että Unto Mononen -muistokonsertteja on tällä vuosikymmenellä yleensäkin järjestetty, saatikka sitten niiden saavuttama menestys, puhuu Monosen nykyisen suosion määrästä.

\section{Toinen ehto: tosi suomalaisuus}

Suosittuja olivat kuitenkin aikanaan myöskin humppa, Henry Theel ja Usko Kemppi. Karsintaa täytyy jatkaa: toinen ehto on, että suomalaisten myyttisten sankarien tulee olla ikäänkuin aivan erityisellä tavalla suomalaisuutta ilmentäviä. Katsaus lehtiartikkeleihin havainnollistakoon tätä. Muutamia esimerkkejä kuluneilta vuosikymmeniltä: "...Monosen kappaleissa on jotakin sellaista ajattomuutta, joka koskettaa jokaista." (Helsingin Sanomat 28.10.1996); "Unto Monosen musiikista ei kai voi olla pitämättä." (Suomen Kuvalehti); "Kaikista Suomen tangosäveltäjistä Unto Mononen kiehtoo meitä suomalaisia kaikkein eniten (...) hän osasi säveltää tangoja tavalla, joka tavoittaa Suomen kansan itkuisen sisimmän paremmin kuin kukaan тии" (ME-lehti, 1/1984). Ja Sama Virrasta: "Hänen (Virran) upea äänensä laulaa lukemattomien suomalaisten muistoja, yhtenäiskulttuurin sielunmaisemaa, joka on nyt kaukana poissa." (Helsingin Sanomat 29.12.1996); "Suomalaisen tangon kuninkaan Olavi Virran tarina on saanut täydennystä..." (Iltalehti 25.3.1996).

Miksi tango on löytänyt tiensä niin vahvasti suomalaisten sydämiin? Tango nousi suosioon sodan jälkeisessä Suomessa ehkä mm. siitä syystä, että tanssilajina se salli suurten ikäluokkien vanhemmille läheisen fyysisen kontaktin tanssiparketilla. ${ }^{2}$ Tango tuli kuin sodanjälkeisen isänmaan tilauksesta vauhdittamaan jällenrakennusta ja väestökasvua. Pirjo Kukkonen (1997, 302 \& 320) taas katsoo tangon olevan osa itkuvirsiperinnettämme, eräänlaista terapiaa ja selviytymisstrategiaa. Kukkonen löytääkin lopullisen syyn suomalaisesta melankolisesta kansanluonteesta, joka löytää tangon mollisoinnuista ja alakuloisesta lyriikasta sopivan äänikulis-

\footnotetext{
${ }^{2}$ Pekka Jalkasen (1991, 9) mukaan kotimaisen iskelmän eräs metafora, pulssi, liittyy hedelmällisyysriittiin. Kaikki suosituimmat seuratanssit, tango mukaan lukien, noudattavat pulssia M.M. 130-140, joka on suurinpiirtein sama kuin sydämen lyöntitiheys orgasmissa.
} 
sin. Kuva hiljaisesta ja melankolisesta suomalaisesta on stereotyyppinen: osaksi totta, osaksi kuviteltua, osaksi itseään ennustava profetia. Tango on osoittautunut käyttökelpoiseksi tämän suomalaisuuden aspektin ilmentämisessä mm. median diskurssissa. Lopputulokseksi tulee joka tapauksessa tangotutkija Pekka Suutarin sanoin: "Tango on humpan ohella suomalaisen tanssimusiikin perussymboli, musiikillinen kielioppi, jossa iskelmän ja tanssimusiikin suomalaisuus kulminoituu" (Suutari 1994, 15).

\section{Kolmas ehto: juoppous}

Tässä käsittelyn alla olevien artistien juoppous ja säälittävä loppu liittyy oleellisesti laajempaan kulttuuriseen yhteyteen, suomalaisen identiteetin myyttisiin alkoholisuhteisiin. Lisäksi tällaisen "heikkouden" merkitys on että se tekee henkilöstä moniulotteisen. Mikäli sankari olisi kaikessa hyvä, olisi kyse yksiulotteisuudesta, joka ei kiehtoisi; Akilleellakin oli kantapäänsä ja Teräsmiehellä kryptoniittinsa. Näyttää siltä, että suomalaisissa myyttisissä sankaritarinoissa nimenomaan alkoholi on kaavamainen "kryptoniitti". Matti Nykäsen törppöily alkoholin vaikutuksen alaisena kuuluu samaan ilmiöpiiriin Monosen ja Virran juopottelun kanssa.

Virran ja Monosen juominen erosi tavallisten ihmisten juomisesta kahdella tapaa: ensinnäkin tämä oli usein liioitellun pakonomaista, ikäänkuin osa työtä. ${ }^{3}$ Toinen, edelliseen liittyvä piirre oli hovi sekä juhlimisen avoin julkisuus, sekä tavoiteltu näyttävyys: näytelmällisiä piirteitä saanut juominen tapahtui esim. Virralla maakuntien kaupunginhotelleissa ja Helsingissä Hotelli Tornin kabinetissa. Samoin keikoilla humalassa esiintyminen ei tietyssä vaiheessa kyseisten artistien kohdalla herättänyt pahennusta, vaan itse asiassa kuului asiaan. Soittajien viinalla kestitseminen on vanhastaan tuttua puuhaa, joka kuului asiaan jo talonpoikaisessa yhteiskunnassa, kuten Asplund (1980) kertoo. Mistä johtuu tämä soittajien sosiaalisesti hyväksytty ylenmääräinen alkoholinkäyttö? Vielä nykyäänkin ainakin piinkovien ammattilaispiirien ulkopuolella soittajien juopottelua pidetään, jos nyt ei toivottavana, niin odotettavana kuitenkin.

Mihail Bahtinin huomiot keskiaikaisesta kansan karnevaalikulttuurista tuovat selitystä tähän kysymykseen. Kansan groteski karnevaali- ja naurukulttuuri oli keskiajalla ja renessanssissa valtavan laajaa ja merkittävää. Bahtinin mukaan kansan naurukulttuuri muodosti vastakohdan keskiajan viralliselle ja vakavalle kirkolliselle ja feodaaliselle kulttuurille. Sen muotoihin ja ilmiöihin kuuluivat mm. karnevalistiset torijuhlat, erilaiset naururituaalit ja kultit, narrit ja hölmöt, jättiläiset, kääpiöt ja hirviöt, ilveilijät sekä valtava ja monimuotoinen parodiakirjallisuus. Virallisen juhlan vastakohtana karnevaali ikäänkuin juhli tilapäistä vapautumista hallitsevasta totuudesta ja vallitsevasta järjestyksestä. Virallinen järjestys oli pysähtynyt, pompöösi ja epätasa-arvoinen, karnevaalissa taas vallitsi tilapäisesti utopistinen vapaus, tasavertaisuus ja runsaus. Karnevaalissa kaikki hierarkkiset

\footnotetext{
${ }^{3}$ Tästä juomisen ja hauskanpidon pakonomaisuudesta on kuvauksia ainakin Von Bagh \& al:n Virtaelämänkerrassa.
} 
suhteet kääntyivät hetkeksi päälaelleen: kaikki katsottiin tasavertaisiksi. Säätyjen, varallisuuden, statuksen säätämät raja-aidat korvattiin silloin tuttavallisella kontaktilla. Karnevaalikielen kuvastoa hallitsevat elämän materiaalis-ruumiillisen ulottuvuuden (Bahtin 19, 1995) - ruumiin, syömisen, juomisen, tarpeenteon ja sukupuolielämän - kuvat. Tätä Bahtin kutsuu groteskiksi realismiksi. Tämän groteskin realismin pääpiirre on alentaminen, kaiken ylevän, henkisen, ideaalin ja abstraktin kääntäminen materiaalis-ruumiilliselle tasolle. Tässä tullaan varsinaiseen groteskin realismin ytimeen: ylhäällä on taivas, alhaalla on maa; maa nielee (hauta, vatsa) ja synnyttää (äidinkohtu). Ihmisruumis on groteskissa realismissa, joka nimenomaan käyttää ihmisruumiiseen liittyviä ilmauksia, suora analogia tälle kosmiselle kahtiajaolle. Samalla tavalla kuin maa sekä nielee ja synnyttää, myös ihmisruumiin alaosa liittyy yhdynnän, siittämisen, raskauden, syntymisen, ahmimisen ja ulostamisen akteihin. Ruumis esittää koko materiaalis-ruumiillista maailmaa olemalla absoluuttinen alapuoli, sekä hauta että kohtu.

1600-luvulta lähtien kansan karnevalismi köyhtyi ja rappeutui, mutta kaventuneessa muodossaan se on ollut olemassa ja on vieläkin, ja Bahtin jopa teostaan kirjoittaessaan uskaltautui puhumaan groteskin uudesta renessanssista viitaten $\mathrm{mm}$. Bertholdt Brechtiin ja Pablo Nerudaan. Voisiko tällä karnevalismilla selittää myös joitakin iskelmäkuninkaiden elämänmenoon liittyviä seikkoja? Kuinka karnevalismi on näkynyt tämän vuosisadan Suomessa? Jotkin ilmiöt ovat suomalaisessa populaarihistoriassa olleet niin ilmeisen karnevalistisia, että erehtymisen mahdollisuutta ei ole. Näissä yhdistyy teatraalisuus ja rahvaanomaisuus, joskus myös karnevalistinen ylettömyys.

Neljäs ehto: sankarin täytyy olla kuollut, ja kuolemasta täytyy olla jo jonkin aikaa

Neljäs ehto on yhteydessä kolmanteen: myyttisen hahmon täytyy olla kuollut, tai ainakin likipitäen. Olavi Virran eläessä käyttivät "mestari"-nimitystä vain kaikkein vannoutuneimmat fanit. Hymy-lehdessä mestarin lopun lähestyessä julkaistuissa muistelmissa nimitys kelpasi otsikoksi jo sellaisenaan, ilman tarkennusta. Kun aikaa kuluu, oikea elämänhistoria ja unohtuu ja korvautuu - elämäntarinaa toki mukailevalla - narratiivisella tarinalla, joka palvelee myytin rakentamisen tarkoitusperiä. Tämä 4. ehto on edellytys 5. ehdon toteutumiselle.

\section{Viides ehto: sankarin elämäntarina}

Kolmas ehto asetetaan enää henkilöille: heidän elämänkohtalonsa tulee toteuttaa tiettyä kaavaa. Monosen ja Virran samankaltainen alkoholiin sortuminen ei ole aivan sattumaa, vaan mm. tämän seurauksena heidän elämänsä olivat sellaisia, että niistä voidaan jälkeenpäin kehitellä myyttiset, dramaturgian lakeja noudattavat nousua ja laskua oikeassa suhteessa ja järjestyksessä sisältävät sankaritarinat, totuutta liikaa muuntamatta. Sankarin elämässä täytyy olla menestyksen lisäksi myös reilusti vastoinkäymisiä - pelkkä triumfi olisi latteaa ja tylsää eikä vetoaisi 
tunteisiin. Todellisen henkilön todellinen elämäntarina, oli se sitten sellaisenaankin kuinka tapahtumarikas ja mielenkiintoinen, tarjoaa usein ainoastaan osan myytin vaatimista rakennusaineista. Eri myyttisyyttä pönkittäviä aspekteja lisäillään ja poistellaan. Helpoiten tämä onnistuu sankarin kuoleman jälkeen, kun faktat alkavat unohtua ja antaa hieman tilaa sepitteelle.

Näytelmä on oivallinen esimerkki myyttisen tarinan kiteyttämisestä. Elämänkerrallinen näytelmä vaatii tehokasta lyhentämistä, koska näytelmän kesto on rajallinen: mukaan pääsevät siis vain oleelliset käännekohdat oikeasta elämästä. Näytelmässä pyritään emotionaaliseen vaikuttavuuteen dramatisoinnin avulla; se, mitä oikeasti tapahtui, ei ehkä sellaisenaan ole aivan tarpeeksi draamallista, ja dramatisoinnin kautta mystifiointiin päädytään ikäänkuin luonnostaan. Tässä artikkelissa analysoinkin kahta elämänkerrallista näytelmää. Tarkoitukseni on löytää kummastakin näytelmästä sama kaava, joka kertoo kuinka myyttiä rakentavia semioottisia rakennelmia voidaan ilmaista tarinan muodossa.

\section{Tarinan merkityksellisyys}

Tarina on globaali ja universaali ilmiö, joka on ollut keskuudessamme kaikkina aikoina, kaikissa paikoissa ja yhteiskunnissa. Sitä on puhutussa, kirjoitetussa ja visualisoidussa muodossa ja lajityyppirajat ylittäneenä myyteissä, legendoissa, saduissa, novelleissa, romaaneissa, tragedioissa, elokuvissa ja arkipäivän keskusteluissa (Törrönen 1997, 16). Mikä on tehnyt tarinasta tällaisen universalismin?

Berger $(1997,2)$ kiinnittää huomion siihen, että erilaiset narraatiot tulevat meille tutuksi aivan elämämme alusta lähtien, vaikkapa lastenloruissa. Bettelheimin (1976) mukaan (Berger 1997) lorut auttavat lasta ymmärtämään psykologisia dilemmoja, sekä tietoisella, esitietoisella että tiedostamattomalla tasolla. Lasten sadut käsittelevät universaalisti lapsia askarruttavia teemoja. Ne kehittävät lapsen egoa ja lievittävät mahdollisia alitajuntaisia ristiriitoja. Kertomus vaikuttaisi olevan sanallisen ilmaisun perustavin laji (esim. Ong 1982, 139-140).

Vanha hittinikkarien hokema, jonka mukaan hittikappaleessa tulee olla sekä uutta että vanhaa, viittaa itse asiassa paljon mittavampaan inhimilliseen käyttäytymiskaavaan kuin vain musiikinkulutukseen. Jalkanen $(1991,7)$ esittää, että toistuvuus ja kertautuvuus "ovat avaimia ratkottaessa populaarisuuden olemusta". Tiettyjen tyylipiirteiden valikoitumisessa muuttumattomiksi, aina vain kertautuviksi rakenteiksi on Jalkasen mukaan takana pyrkimys viitata myyttiseen kollektiiviperinteen aikaan ja sykliseen aikakäsitykseen. Haettaessa suuren yleisön yhteistä nimittäjää on palattava kauas kansan mentaalihistoriaan, aikaan jolloin "varioimattomuus, epäoriginellius oli positiivinen arvo, turvallisuuden tunteen tae ja kulttuurin jatkuvuuden elinehto". Tiedetään toiston luovan turvallisuuden tunnetta. Pertti Alasuutari kertoo narratologiaa sivuavassa kirjoituksessaan $(1991,8)$ pojastaan, joka haluaa aina kuulla saman iltasadun, kertoen vain aluksi joka ilta muuttuvat tarinan pintatason spesifikaatiot. Alasuutari toteaa meidän aikuisten katsovan televisiota samalla tavalla. Kun ryhdymme katsomaan jonkin tietyn lajityypin ohjelmaa, tiedämme jo ennakkoon juonenkäänteet suurinpiirtein. Alasuutari toteaa, 
ettei tällaista esitietoa ole ainoastaan massakulttuurin tuotteista, vaan että sama pätee muihinkin kertomuksen tyyppeihin, kuten kansantarinoihin ja satuihin. Itse asiassa näille asetetaan tällainen vaatimus. Niinpä teollisesti tuotetun viihteen kaavamaisuus ei ole teollisuuden vehkeilyä, vaan yleisön asettama ehto.

Kertomus on muutoksen eli tapahtuman, toiminnan tai teon kuvaus. Ts. jos mitään ei tapahdu, ei ole tarinaakaan. Kuitenkin on niin, että koska tarina on niin vahva inhimillisen ajattelun tapa, ihminen keksii tarinan siihen missä sitä ei muuten ole: jos näemme "rantojen miehen" tarkistamassa roskiksen sisältöä, alamme miltei vaistomaisesti kuvitella mikä tapahtumien ketju ihmispolon tuohon pisteeseen on tuonut. Lisäksi monet asiat, joita emme tapaa ajatella juonellisiksi, pitävät tarkemmin ajateltuna sisällään kertomuksellisia komponentteja: tavalliset arkikeskustelut, sairauksien kulut, rakkaussuhteet ja psykoterapiaprosessi esimerkiksi (Berger 1997, 15).

Aarne Kinnunen (1991, 82-85) kertoo olevan kahdenlaisia tarinoita. Välittömät kertomukset ovat sellaisia, joissa viesti siirtyy henkilöltä toiselle, ja kerrottu viittaa todellisuuteen. Toinen kertomuksen laji on metakertomukset. Tällöin on kyse kertomuksesta kertomuksesta. Kertoja määrittelee kertomuksensa joksikin: romaaniksi, legendaksi, anekdootiksi jne. Kinnunen esittää empiiriseksi tosiasiaksi, että ei ole kulttuuria ilman tällaisia metakertomuksia, myyttejä, taruja, eepoksia jne., koska kulttuuriin kuuluu traditio, ja traditio on mahdoton ilman kertomusta. (Ibid., 105) Kulttuuriin siis kuuluu epämääräinen joukko kertomuksia, jotkut vähemmän tärkeitä ja jotkut tärkeitä, varsinaisia ydinkertomuksia.

\section{Aktanttimalli}

Vaikka innostus strukturalismiin on 80-luvun kultakauden jälkeen aika tavalla hiipunut, on tästä perinteestä jäänyt jäljelle monenlaisia semioottisia työkaluja, joita voidaan menestyksekkäästi soveltaa semioottisten rakenteiden hahmottamiseksi kielellisistä ilmauksista kuten vaikkapa näytelmistä. Strukturalistisen suunnan yhdenlaista huipennusta merkitsevät A. J. Greimasin kehittämät aktanttimalli ja narratiivinen kaavio. Niissä Greimas kehitti Vladimir Proppin aloittamaa ja Claude Lévi-Straussin jatkamaa tarinoiden rakenteen tutkimisen linjaa. Vladimir Propp tutki Venäläisiä ihmesatuja ja tunnisti niistä yleisen rakenteen, joka koostuu tapahtumien sarjasta. Nämä tapahtumat Propp ymmärsi funktioiksi, joilla oli aina oma toteuttajansa. Ilmitasolla toteuttajat vaihtelivat, mutta erilaisten toteuttajien määrää voidaan vähentää tiivistämällä toteuttajat omiin funktiokategorioihinsa: esim. tarinan roisto voi olla noita, lohikäärme, paha äitipuoli jne.. Proppin analyysi kuitenkin pureutui vain tarinoiden pintatasoon, Lévi-Strauss kehitti omaa teoriaansa Proppin pohjalta, mutta nyt myös syvätasoon pureutuen. Tämä syvätaso ilmenisi Lévi-Straussin mukaan myyteissä, joiden tehtäväksi Lévi-Strauss näki käsitellä kulttuurin sisäisiä jännitteitä. Syvätaso perustuu vastakkaisille käsitteille kuten kulttuuri - luonto. Kertoessaan jostain perustavasta ristiriidasta ja tavasta jolla tämä ratkaistaan, myytit ilmentävät kulttuurin hyväksymiä ja torjumia arvoja. LéviStrauss siis lisäsi Proppin syntagmaattiseen ulottuvuuteen paradigmaattisen 
ulottuvuuden.

Näistä kahdesta A. J. Greimas yhdisteli ja kehitti oman mallinsa (Korhonen \& Oksanen 1997, 56-57). Hän lisäsi edellisiin henkilöhahmojen ja muiden tarinan entiteettien välisten suhteiden analyysin. Greimas tiivisti Proppin funktioluetteloa entisestään ja sai tulokseksi aktanttikaavion, narratiivisen kieliopin peruskaavan, joka perustuu lähettäjän ja vastaanottajan, subjektin ja objektin, sekä auttajan ja vastustajan välisille suhteille. Greimasinkin kohdalla samoja käsitteitä voidaan soveltaa kaikenlaisiin kielijärjestelmiin musiikista arkkitehtuuriin. Greimasin teoria on kokoelma loogisia tulkinnan apuvälineitä. Sulkunen $(1997,35)$ painottaa ettei Greimas tarjoa mitään filosofista teoriaa merkityksestä yleensä, vaan kylläkin loogisia ja havainnollisia tulkinnan työkaluja.

Analysoin seuraavaksi kaksi näytelmää käyttäen hyväksi Greimasin aktanttikaaviota. Aktantit ovat kaikissa tarinoissa esiintyviä suhdekategorioita. Tärkein näistä on subjektin ja objektin välinen suhde. Kaikkia näitä suhteita määrittää jokin pragmaattisen modaalisuuden lajeista: haluaminen, osaaminen, kykeneminen ja täytyminen. Kuvatun maailman eri aktanttien väliset suhteet saavat näiden kautta "mielen", ilman näitä pragmaattisen modaalisuuden lajeja ei syntyisi mitään toimintaa. Esimerkiksi tärkein subjektin ja objektin välistä suhdetta määrittävä modaalisuuden laji on "halu".

Mallissa lähettäjä motivoi subjektin tavoittelemaan objektia ja määrittää toiminnan päämäärät. Auttaja tukee subjektia, kun taas vastasubjekti ja vastustaja yrittävät estää tavoitteen saavuttamista. Tehtävän lopussa vastaanottaja arvioi toiminnan onnistumista palkitsemalla tai rankaisemalla osallisia. (Korhonen \& Oksanen, 56-57; Greimas 196-219, 1980) Aktanttimalli on analyysin käsitteellinen apuväline, jolla tarinan analyysissä päästään alkuun. Sulkunen \& Törrönen (1997, 77) painottavat, ettei aktanttikaaviota pidä ymmärtää liian kirjaimellisesti. Yleensä jokaiseen aktanttiasemaan ei suinkaan sijoitu eri toimija. Vastaanottaja ja lähettäjä voivat olla sama toimija, jopa sankari-subjekti itse. Toimijoiden asema voi myös vaihtua tarinan kuluessa, niinkuin Hitchcockin elokuvan sankari paljastuessaan jossain vaiheessa psykopaatiksi.

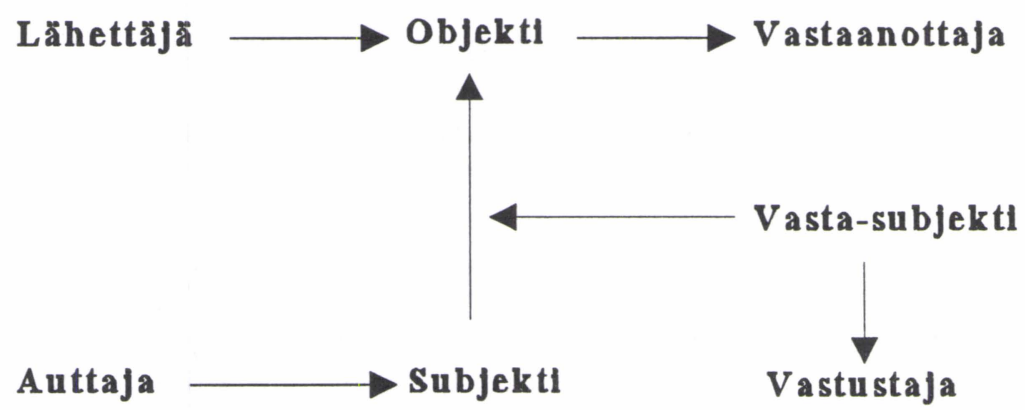

Tarinassa kuvataan asioiden kulkua subjektin näkökulmasta. Subjekti on tarinan alussa ilman objektia, jonka lähettäjä tämän velvoittaa tavoittelemaan varustaen 
subjektin kyvyllä, halulla, kompetenssilla ja velvoitteella, jolloin toiminta alkaa. Vastasubjektin aiheuttamien hankaluuksien jälkeen subjekti saa objektin ja alussa ollut puute poistuu. Tarinan ydin siis muodostuu subjektin ja objektin suhteen muutoksesta. (Korhonen \& Oksanen 1997 59) Greimas on laatinut narratiivista kulkua jäsentävän kolmiosaisen kaavion. Narratiivisen kulun kaavio muodostuu kolmesta ideaalitarinan vaiheesta.

1. Kvalifioivassa (valmistavassa) tarinassa lähettäjä varustaa subjektin velvoitteella, motivaatiolla ja kyvyllä tehtävästä selviytymiseksi.

2. Päätarinassa subjektin kyvyt joutuvat koetukselle vastasubjektin ja vastustajan yrittäessä estää objektin saavuttamisen.

3. Sanktioivassa tarinassa aktanttien toimintaa arvioidaa; vastaanottaja palkitsee ja rankaisee osallisia. (Korhonen \& Oksanen 1997, 59; Greimas 1980, 225)

Sovellan seuraavaksi aktanttimallia kahden näytelmäkäsikirjoituksen rakenteelliseen analyysiin. Arto Niemisen kirjoittama Erottamattomat on laulunäytelmä Unto Monosesta vuodelta 1998. Kun ilta ehtii on Erkki Auran ja Erkki Wessmannin kirjoittama, vuonna 1988 kantaesitetty musikaali Olavi Virrasta. Kumpikin näytelmä pyrkii mukailemaan päähenkilöidensä historiallisia elämänkohtaloita. ${ }^{4}$

Näytelmissä on huomionarvoista niiden historiallinen puutteellisuus, onhan selvää että eri kohtauksia voi olla vain rajallinen määrä. Mitä sitten on jätetty pois? Tässä huomaammekin mielenkiintoisen seikan: koska näytelmien henkilöt ovat historiallisia henkilöitä, ja juonissa pitäydytään pitkälti jo aiemmin dokumentoiduissa, oikeasti tapahtuneissa tapahtumissa, on katsojilla jo juonta koskevaa ennakkotietoa. Useat nämä näytelmät nähneet asian harrastajat ovat itse asiassa tienneet juonen melko tarkalleen jo ennalta. Niinpä näytelmiin on ollut mahdollista jättää ajallisia ja tapahtumallisia aukkoja, koska katsojat kyllä tietävät mitä näiden "aukkojen" aikana tapahtuu. Kumpikin näytelmä esimerkiksi loppuu päähenkilöiden kuolemaan. Kuitenkin, kuten tulen edempänä todistamaan, tarina jatkuu vielä tämän jälkeen.

Tässä melko alustavassa yrityksessä edellä kuvailtujen rakenteiden hahmottamiseksi yritän hahmottaa näytelmistä aktanttikaavion mukaisen rakenteen. Havainnollistan analyysiäni kuvailemalla ja lainaamalla näytelmistä löytyviä avainkohtia ja -repliikkejä. Näytelmien juonien analyysi alkoi siten, että tiivistin jokaisen kohtauksen tapahtumat yhteen kappaleeseen. Erottamattomat-näytelmässä kohtauksia oli 12 , Kun ilta ehtii-näytelmässä 30 . Koska ko. näytelmät ovat musikaaleja, liittyi miltei kaikkiin kohtauksiin musiikkiesityksiä, joihin kuitenkin harvoin sisältyi mitään juonenkuljetuksellista funktiota. Kun ilta ehtii-musikaalissa juonta kuljettaa usein kertojan ääni. Kummassakin näytelmässä eri kohtausten välillä saattoi olla suuria ajallisia harppauksia. Kumpikin näytelmäkäsikirjoitus sisälsi kaikesta päätellen oletuksen, että katsojilla on ennakkotietoja päähenkilöistä: mm.

\footnotetext{
${ }^{4}$ Ensin mainittuun on vaikuttanut olemassaoleva Unto Monosen elämänkertakirja, päätellen joidenkin yksittäisten tapahtumien kuvausten samankaltaisuudesta. Virta-näytelmän taustalla taas vaikuttavat toisen kirjoittajan 1960- ja 70-luvuilla kirjoittamat lukuiset Virta-aiheiset, osin elämänkerralliset lehtijutut.
} 
näytelmien roolihenkilöiden joukossa oli sellaisia historiallisia henkilöitä, joiden statusta ei näytelmissä sen kummemmin selitelty, vaan näiden tunnistaminen jäi katsojan vastuulle. Vaikka juonenkulun ymmärtäminen onnistuneekin ilman näiden henkilöiden ja tapahtumien tunnistamista, niin näytelmien anti joka tapauksessa jää katsojille köyhemmäksi, mikäli kohtauksia ei osaa kytkeä historiallisiin yhteyksiinsä. Tosin on niin, että tämä pitää usein paikkansa silloinkin, kun näytelmä ei käsittele historiallisia tapahtumia, mutta on kytketty tiettyyn aikakauteen, paikkaan jne.

Näytelmien tapahtumat olivat kutakuinkin kronologisessa järjestyksessä, tosin sillä poikkeuksella, että kummankin näytelmän avauskohtaus oli siirretty alkuun kronologisen järjestyksen loppupuolelta. Kumpikin näytelmä päättyi päähenkilön kuolemaan. Järjestettyäni kohtaukset kronologiseen järjestykseen, voidaan näytelmien juonet hahmottaa Greimasin narratiivisen kulun kolmijaon mukaisesti:

\section{Valmistava tarina}

Erottamattomat: Nuori Unto Mononen aloittelee sävellyspuuhiaan Somerolla. Muita hahmoja tässä vaiheessa ovat kannustava kaverinsa Matti Paloposki sekä Untoa "oikeisiin" töihin ja naapurin tyttären kanssa naimisiin painostava, mutta kuitenkin poikaansa tukeva Unton äiti. Unto on kuitenkin tehnyt päätöksensä, ja lähettelee määrätietoisesti tuotoksiaan levy-yhtiöihin saaden lopulta ensimmäisen sävellyksensä levytettyä. Alkoholinkäytöstä annetaan viitteitä jo tässä vaiheessa. Valmistava tarina on lyhyehkö, vain puolentoista kohtauksen mittainen.

Kun ilta ehtii: Virta esiintyy ensimmäistä kertaa laulajana Heimolan tanssipaikassa Helsingissä 1936 ja herättää levymoguli Niilo Saarikon ja Toivo Kärjen huomion. Tässä yhteydessä ottavat paukut, Olavi tässä vaiheessa vielä vastentahtoisesti. Olavi tekee ensilevytyksensä, ja tämän jälkeen paljon levyjä talvisotaan asti Saarikon suojeluksessa. Rintamalta Virta kirjoittaa äidilleen Ida-Marialle halunsa ryhtyä musiikin ammattilaiseksi. Äiti on huolissaan poikansa ammatinvalinnasta. Välirauhan aikana Olavi rakastuu tulevaan vaimoonsa Ireneen. Jatkosotaan Virta lähtee viihdytysjoukoissa. Sodan jälkeen Olavi on musiikin tosiammattilainen.

\section{Päätarina}

Erottamattomat: Valmistava tarina muuttuu päätarinaksi kesken kohtauksen. Unton ensilevy saa osakseen väheksyntää kyläläisiltä, koska on vain levyn b-puoli. Myös vallankäyttäjä ja portinvartija Toivo Kärki on nyt läsnä käskemässä ottamaan oppia omista tuotoksistaan. Kärjen vallankäyttäjän suhde riippuvaiseen Monoseen on päätarinan keskeisin juonne: jo näytelmän avauskohtaus, Unton yritys päästä sihteerin ohi johtaja Kärjen pakeille on siirretty alkuun päätarinasta. Toinen päätarinan punainen lanka on Unton raju juopottelu.

Muita keskeisiä henkilöitä ovat Unton orkesterin solistit Hellä ja Hili, joista 
jälkimmäisen kanssa Unto astuu myös avioon. Suhde Hellään, Hiliin sekä Hilin seuraajaan Lainaan katkeaa vuorollaan Unton holtittoman alkoholinkäytön ja elämänmenon takia. Myös äiti kuolee. Näiden lisäksi tarinaan tulee mukaan Esko Rahkonen ja M. A. Numminen, jotka tekevät Unton kanssa yhteistyötä. Ohimennen mainitaan myös Scandia-levy-yhtiön tuottaja Jaakko Salo, joka haluaa levyttää Unton "Satumaa"-tangon (Salolla ja Scandialla oli suuri rooli Monosen uran huippukauden aikana). Unton rappiokierre kuitenkin jatkuu ja johtaa kuolemaan. Lopussa näyttämöllä ovat Unton lisäksi Toivo Kärki, Esko Rahkonen, M. A. Numminen sekä Helena-äiti. Nämä ovat surullisia Unton kohtalon johdosta, mutta alistuvat siihen. Kärki antaa hieman tunnustusta Monosen tangoille, mutta vieläkin mainitsee "puutteista luovuudessa". Näytelmä loppuu tähän.

Kun ilta ehtii: Olavi ja Irene ovat naimisissa ja heillä on lapsia. Olavi on kuitenkin kiireinen, eikä ehdi olla tarpeeksi kotona. Saarikko soittaa Virran laulamaan Hotelli Tornin kabinettiin kesken viihtyisän koti-illan (Tornin kabinetit olivat 50luvulla Virran ystäväpiirin keskeinen juhlimisareena). Irene on tyytymätön, samoin Pauli-poika, josta alkaa tässä vaiheessa tulla roolihenkilö. Aikaisemmin hän on jo ollut läsnä kertojanäänenä. ${ }^{5}$ Olavin ura on kuitenkin huipussaan. Virta ja Saarikko käyvät Amerikassa, jossa tapaavat Dave Brubeckin ja juovat 50 viskiä päivässä. Olavi tuo kotiin mm. amerikanraudan. Kotona menee kuitenkin yhä huonommin, Irene saa Olavia panettelevia parjaussoittoja, ja Olavi pakenee riitoja rakastajattarensa Anneli Saulin luo, jonka luona Olavi saa ymmärrystä ja voi rentoutua. Tummat pilvet alkavat kerääntyä, toimittaja Maunula alkaa kehitellä toimituksessa jotain Virran päänmenoksi. Tapahtuu surullisenkuuluisa Ilomantsin keikka, jonka tapahtumia vääristellään lehdistössä (Virta muka rapakännissä). Virta saa lisänimen "laulava lihapulla", ja onkin samantien konkurssissa. Samaan aikaan Irene lähtee Ruotsiin, Pauli-poika jää Olaville Helsinkiin. Ryyppääminen yltyy. Toivo Kärjen kertojan ääni kertoo Virran alamäestä. Pauli yrittää itsemurhaa ja syyttää isäänsä. Virta tilittää elämäänsä Paulin vuoteen äärellä ja poistuu sitten näyttämöltä. Kronologisesti tähän kohtaan kuuluu myös näytelmän avauskohtaus, jossa Virta kertaa elämäänsä juuri taitelijaeläkkeen saaneena. Viimeisessä näytöksessä Virta haudataan; viimeisenä seppeleen laskee haudalle Hulda Simula (jonka luona Virta vietti perin vaatimattomissa oloissa elämänsä viimeiset vuodet).

\section{Sanktioiva tarina}

Mutta näytelmäthän loppuivat jo? Kyllä, mutta tarina jatkuu, ja tässä tarinan viimeisessä vaiheessa, sanktioivassa tarinassa on osallinen myöskin Kun ilta ehtii ja Erottamattomat -näytelmiä katsomaan saapunut yleisö. Monosen ja Virran henkilöhahmojen kuolemanjälkeinen "elämä" on kaikkien tiedossa. Implisiittisesti tarinan jatkoon viitataan jo Virta-näytelmän viimeisessä kohtauksessa, jossa kertojan ääni lukee Olavi Virran muistokirjoituksen. Muistokirjoituksessa todetaan

\footnotetext{
${ }^{5}$ Alkuperäisissä Seinäjoen kaupunginteatterin esityksissä Pauli Virta esitti itseään.
} 
mm. seuraavasti: "Laulajaa jäivät kaipaamaan hänen läheisensä sekä koko Suomen kansa."

Juoni jatkuu seuraavasti: Mononen ja Virta muodostuvat kuolemansa jälkeisinä vuosina suomalaisen populaarimusiikin käsitteiksi. Virta saa oman patsaansa 1984 Tampereelle, Mononen 1996 Somerolle. Kumpikin on saanut myös elämänkertakirjansa. 1985 ryhdytään Seinäjoella järjestämään vuotuisia Tangomarkkinattapahtumia, josta kehittyy nopeasti yksi Suomen suurimmista festivaalitapahtumista. 1988 tangomarkkinoilla esitetään "Kun ilta ehtii" -musikaali, suurproduktio Olavi Virran elämästä. 1995 Seinäjoelle pystytetty Olavi Virta-näyttely keräsi muutamassa päivässä 7000 kävijää. ${ }^{6} 1996$ valmistuu mittava levyprojekti, jonka tuloksena koko Olavi Virran levytetty tuotanto, yhteensä 600 laulua jälleenjulkaistaan 29 CD-levyllä. ${ }^{7}$ Vuonna 1995 Monosen "Satumaata" soitetaan Yleisradion eri kanavilla yli 200 kertaa, mikä tekee siitä sen vuoden soitetuimman kappaleen (Gronow 1997, 29). Unto Mononen saa nimeään kantavan yhdistyksen vuonna 1993. Yhdistys on julkaissut äänitteillä Monosen jälkeenjääneitä sävellyksiä sekä järjestänyt useita suuren suosion saavuttaneita muistokonsertteja. Halukkaille on tarjolla Mononen T-paitoja, pinssejä sekä oluttuoppeja. Someron keskustassa oleva hotelli on nimetty "Satumaan" mukaan - kappaleen, jota on ehdotettu myös virsikirjaan. Unto Monosta ja Olavi Virtaa ei todellakaan ole unohdettu. Vaikka fyysisesti henkilöt ovat kuolleet jo kolme vuosikymmentä sitten, nämä suomalaisten rakastamat hahmot ovat läsnä vieläkin hyvin monessa muodossa, kuolemattomina. Tarinan viimeinen vaihe loppu vasta tähän.

\section{Tarinoiden aktantit}

Subjektit, Virta ja Mononen, ovat tarinan alussa ilman objektia. Mikä on tämä objekti, jonka olemassaolo antaa tarinalle tarkoituksen? Pintatasolla tavoitellaan yleisönsuosiota. Sekä Mononen että Virta ovat käytännön miehiä, jotka tekevät sellaista musiikkia mikä myy; Mononen muuttaa vanhat foksinsakin paremmin myyviksi tangoiksi. Paljastavaa on kuitenkin Monosen palava halu säveltää jonain päivänä parempi tango kuin Kärki. Kun M. A. Numminen toteaa kahdeksan kärjessä olevan "Topi, Topi, Topi...", uhoaa Mononen sen vielä joskus olevan "Unto, Unto, Unto". Kun valtavan suositun Kärjen jo hänen elinaikanaan tiesi tehneen pysyvän merkkinsä iskelmän historiaan, tietäisi hänen kruununsa riistäminen kuolemattomuutta Monosellekin. Todellinen tähtäin on siis asetettu pelkkää yleisönsuosiota korkeammalle, kuolemattomuuteen. Jo näytelmän alussa Unton ystävä Matti tituleeraa Untoa Sibeliukseksi ja ennustaa Unton pääsevän vielä pitkälle. Myös Unto ennustaa: "...miun perhosein lentää liihottaa viel sitkii ko miust aika jättää." Unto vihjailee tulevasta kuolemattomuudestaan toistekin. Toivo Kärjelle Unto sanoo: "Kuule Topi, me ollaan jo muututtu öljyksi kun tango vielä

\footnotetext{
${ }^{6}$ Olavi Virta. Tangon ja viihteen hovi -näyttelyn esite

${ }^{7}$ Iltalehti 25.3.1996
} 
repii ja raiskaa härmäläistä tajuntaa. Se ei kuole koskaan." Virran ensilevytyksessä tuottaja Saarikko myös käskee soittajia painamaan päivämäärän mieleen: "Ties vaikka tehtäisiin suomalaisen iskelmämusiikin historiaa." Saarikko onkin Virran tarinassa selkeä lähettäjä, joka motivoi subjektin tavoittelemaan objektia ja määrittää toiminnan päämäärät, sekä varustaa subjektin kompetenssilla: "Laulajaksi tullaan vain kovalla työllä ja lahjakkuudella. Sinulla tuntuu olevan taipumuksia molempiin." Monosen kohdalla mesenaattia ei ole, ja lähettäjänä saa uhota lähinnä hän itse.

Perimmäinen lähettäjä paljastuu kuitenkin vasta kun tarinan edetessä alkuperäinen objektia tavoittelemaan motivoinut modaalisuuden laji "halu" muuttukin huomaamatta "velvollisuudeksi". Kun Anneli Sauli kysyy stressaantuneelta Olavilta, että "Kuka sinua pakottaa joka helvetin lavalle", vastaa Olavi: "Suomen kansa". Samoin Virta sanoo aina lavalle noustessaan mielessään olleen yhden asian: "Kuules Olavi, sinä laulat nyt Suomen kansalle eikä siinä passaa bluffata." Vaikka Mononen ei näytelmässään näyttäydykään Virran kaltaisena työn sankarina, kansan tarpeeseen hänkin musiikkinsa tekee: pitkä alkusoitto, jotta miehet ehtivät hakea daaminsa rauhassa, sekä pitkät välisoitot "joissa voi lyödä pään munkkien väliin ja puristella senjoriittaa pakaroista". Molemmat sankarit siis kokevat kansan paitsi vastaanottajaksi, siksi jolle "annetaan", myös lähettäjäksi, siksi joka "vaatii".

Vastasubjekti henkilöityy Monosen kohdalla Toivo Kärkeen ja Virralla toimittaja Maunulaan. Mononen on Kärjestä riippuvainen, ja Kärki ei missään vaiheessa rohkaise, vaan päinvastoin hän kutsuu Monosen tuotteita "fylliksi", täytemateriaaliksi. Toimittaja Maunulaa taas ärsyttää Virran vuosikausia kestänyt menestys, ja hän kokee ajan olevan kypsä kuninkaan alasampumiseen. Tässä hän onnistuu mainiosti - yksi ainoa lehtijuttu tuntuu käynnistävän ketjureaktion, jonka päättyessä Virralta on mennyt kaikki. Myös se sama suuri yleisö, joka Virran nosti, tarttuu hanakasti täkyyn ja tulee nyt tanssipaikoille katsomaan lähinnä Virran rappiotilan edistymistä. Vastasubjekteja auttava vastustaja on sekä Monosen että Virran tarinassa sankarin alkoholismi. Alkoholismi on tässä tapauksessa se heikkous, mikä tekee sankareista moniulotteisia hahmoja. Vastustaja on siis sankareissa itsessään. Entä mikä on se yhteinen nimittäjä, jota sekä Monosen että Virran vastasubjektit edustavat? Se on pohjimmiltaan arvostuksen puute. "Erottamattomissa" tämä tuodaan esille heti alustavan tarinan ja päätarinan leikkauskohdassa, kun onnensa kukkuloilla olevan Monosen ympärillä olevat kyläläiset alkavat vähätellä Monosen uunituoretta ensilevytystä: "Kakkospuoli? Vaan?" Loppupuolella kun ystävä yrittää lohdutella masentunutta Monosta sanomalla Suomen kansan rakastavan tämän tangoja, vastaa Mononen: "Mutta ei minua, ihmisenä en ole mitään, en kukaan". Myös Virralla oli syytä katkeruuteen: ensimmäistä suomalaiselle viihdetaiteilijalle pitkän taistelun jälkeen myönnettyä taiteilijaeläkettä Virta ehti nautti kokonaista kaksi kuukautta ennen kuolemaansa. Virallinen tunnustus tuli liian myöhään: "Jumaliste kun nousee tuhansia kertoja yleisön eteen vetoisissa työväentaloissa tai avolavoilla, jonne tuuli vapaasti puhaltaa ja silti laulaa joka kerta täysillä, niin se on takuulla ihmisen kannalta samanarvoista kuin mikä тии taiteeksi kutsuttu ja maksettu tahansa."

Auttajia oli Monosella varsinainen kavalkadi: Äitinsä Helena, orkesteriensa 
solistit, ystävänsä Matti, Esko Rahkonen ja M. A. Numminen. Virran auttajia näytelmässä taas olivat Niilo Saarikko - tämä tosin varauksella, koska oli aina tuputtamassa viinaa - sekä Anneli Sauli. Auttajista suurin oli kuitenkin kummallakin sama: tango. Mononen sai kiittää kaikesta tangoa. Virran levytystuotannosta tangojen osuus ei ollut mitenkään leimallinen, ei edes osuus menestyskappaleista, mutta jälkipolvet mieltävät hänet nimenomaan tangolaulajaksi, kliseenomaiseksi "tangokuninkaaksi". Nyt voimme täydentää aktanttikaavion lopulliseen muotoonsa:

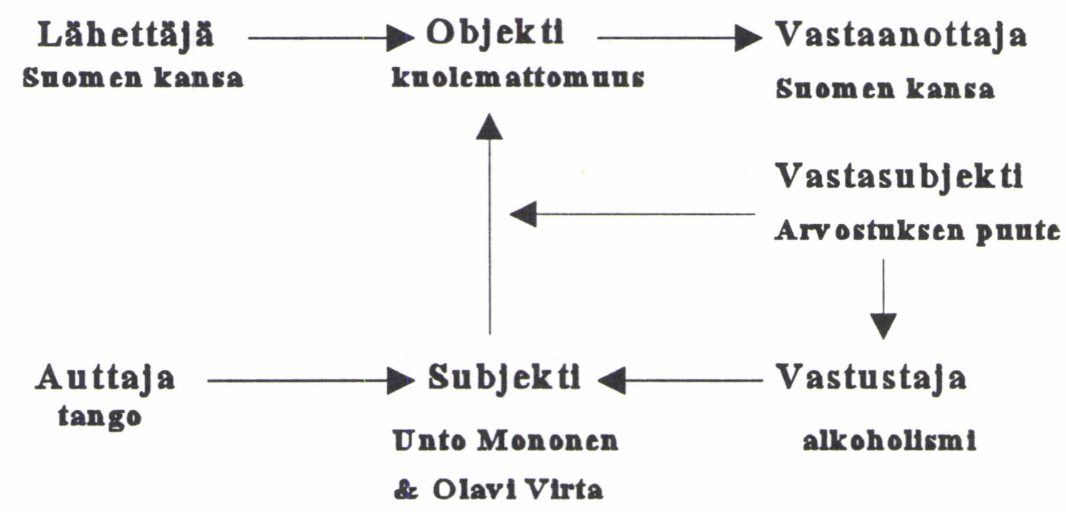

\section{Myytin määrittely}

Olen säästänyt myytin käsitteen määrittelyn viimeiseksi, samaan yhteyteen tässä artikkelissa käsiteltyjen myyttien merkityksen selvittämisen yhteyteen. Myytin käsitteellä on hieman eri merkityksiä tieteenalasta riippuen: sekä antropologiassa, psykologiassa että kirjallisuustieteissä on havaittu ko. käsitteen käyttökelpoisuus tietynlaista inhimillistä ajattelutapaa kuvattaessa. Esimerkiksi kansanperinnetutkimuksessa myytti on määritelty lähinnä syntykertomukseksi, joka selittää erilaisten ilmiöiden, luonnonilmiöiden, ihmisen, universumin tms. alkuperää. Tällöin myyttisyydellä viitataan arkaaiseen maailmankuvaan, yhteisöihin, joissa myyteillä jäsenneltiin maailmaa paremman keinon puutteessa.

Tässä artikkelissa myytin käsite määritellään hieman tästä poikkeavasti. Falk \& Sulkunen (1980) ovat tutkiessaan humalan myyttisiä merkityksiä suomalaisissa elokuvissa tehneet eron myyttisten ja instrumentaalisten sosiaalisten merkitysten välille. Kun sosiaalinen merkitys voidaan ilmaista sanallisesti, on kyse instrumentaalisesta merkityksestä. Sulkusen ja Falkin esimerkkiä käyttääkseni: kun tarjoan vierailleni ouzoa, annan näin ehkä ymmärtää että olen ihminen, joka käy ulkomailla, enkä käytä alkoholia pelkästään humaltuakseni jne. Nämä kaikki on mahdollista sanoa myöskin suoraan. Aina ei esim. edellä havainnollistetun tavaramaailmankaan kieli ole kuitenkaan jatkoa tavalliselle arkikielelle. Falk \& Sulkunen antavat esimerkiksi nuorisomuodin ikonisine viittauksineen erilaisiin nuorisokulttuurin edushahmoihin. Näissä viittauksissa on kyse metaforallisista suhteista, samoin kuin 
vaikkapa suomalaiseen viinankäyttöön usein kuuluvalla tappelulla, jonka sosiaalisia merkityksiä ei voi arkipuheella selittää. Tällaisia "toiseen todellisuuteen" kuuluvia merkityksiä Falk \& Sulkunen kutsuvat myyttisiksi. Henri Broms taas määrittelee teoksessaan "Alkukuvien jäljillä" (1984) myyttien olevan ihmisen arvomaailmaan kuuluvia käsitteitä jonkin populäärin kuvan muodossa.

Lopuksi todettakoon: myytit ovat aivan yhtä todellisia kuin fyysinen ympäristö. Myyttistä ajattelua harvoin ymmärretään sellaiseksi, sillä se, $\mathrm{mm}$. politiikassa, puetaan usein loogisen syysuhteisen ajattelun kaapuun (Ibid.). Toisaalta myytti on usein jonkinlainen itsestäänselvyytenä pidetty asia, eli kuten Roland Barthes (1994) on huomioinut, sanonnanomaiseksi pyrkivä

\section{Mononen, Virta ja tango kansallisen kulttuurin myytteinä}

Yleensä semiootikolle oman kansallisen kulttuurin analyysi tapahtuu luontevimmin siten, että lähdetään särkemään myyttejä ja paljastamaan niiden mekanismeja (Tarasti 1990, 197). Taustalle kuvitellaan useimmiten joku taho, joka käyttää näitä myyttejä omien tarkoitusperiensä edistämiseen. Tämä onkin Tarastin mukaan eräällä tavalla helpompaa kuin itse analyysi, koska hyväksikäyttäjän ei tarvitse todistaa semiologista tapahtumaketjua - riittää, että semioottinen mekanismi toimii käytännössä. Niinpä semioottisen mekanismin hyödyntäminen voi tapahtua myös enemmän tai vähemmän vaistomaisesti. On myös liioiteltua olettaa, että joku taho pystyisi tyhjästä luomaan vaikkapa jonkin kansallisen myytin. Myytin on oltava olemassa, ainakin "ilmassa", jotta se voidaan valjastaa hyötykäyttöön. Tarastin mukaan usein on niin, että jokin kulttuurituote ei alun perin ole tarkoitettu kansalliseksi, vaan se ulkopuolisten tekijöiden vaikutuksesta tulkitaan ajan mittaan tällaisena. Suomalainen kulttuuri, joka on muiden kulttuurien välisessä kulttuurivaihdossa ollut aina enemmän saamapuolella, on kehittynyt erityisen eteväksi ulkomaisten kulttuurituotteiden "suomalaistamisessa", välttämättömyyden edessä. Tango on tästä oikein hyvä esimerkki.

Tarasti (Ibid. 203-204) esittää, että kansallisessa kulttuurissa on kaksi 'semioottista' kehitysvaihetta. Ensin ikonit 'luodaan': jo valmis, abstrakti käsitteistö konkretisoidaan kansallisella merkityksellä, tai sitten taiteilijat, tieteilijät ja kansakunnan merkkihenkilöt itse luovat nämä ikonit ja markkinoivat kansalle. Toisessa vaiheessa ryhdytään tuottamaan uusia kansallisia ikoneja jo valmiista ensimmäisen vaiheen ikoneista lähtien: kansallisuutta ei enää luoda, vaan sitä vaalitaan. Tämä on tyypillinen folklorismin vaihe, jähmeiden ja juhlallisten riittien aikaa. Tarasti esittää esimerkkinä elämänkerrat, jotka ovat muuan kansallisen kulttuurin pysyvä ja keskeinen tekstilaji. Niitä tuotetaan nimenomaan kasallista kulttuuria tukevaksi esimerkiksi muille yhteisön jäsenille.

Kansallisen kulttuurin ensisijainen kiinnostus on sen itsensä säilyttäminen ennallaan. Tarkoituksena on luoda sellaisia käyttäytymisen mekanismeja, jotka takaavat tiettyjen asenteiden, arvostuksien ym. säilymisen mahdollisimman kauan. (Ibid.) Minun tulkintani mukaan Unto Monosen, Olavi Virran ja tangon myyttien rakentamisessa on kyse kansallisen kulttuurin pönkittämisestä, vastaamisesta 
kansan syvien rivien huutoon ahdistavassa globalisaation ajassa - sekä siinä sivussa pienen bisneksen teosta. Myytin rakentaminen, tai rakentuminen, jos halutaan välttää kuvittelemasta ketään tietoista tahoa, alkoi 1960- ja 70-lukujen vaihteessa, jolloin Suomessa tapahtui raju elinkeinorakenteen muutos maatalousvaltaisesta teolliseen ja tähän liittyvä maalta kaupunkiin muutto. Heti tästä selvittyämme on vuorossa sopeutuminen yhdentyneeseen Eurooppaan ja globaaliin taloudelliseen kilpailuun. Ahdistusta lievittämään tarjotaan mm. viihdespektaakkeli Seinäjoen tangomarkkinoita, joka nojaa kansalliseen tangoinstituutioon sekä sen kliseiden korostamiseen ja pysyvyyden pönkittämiseen.

\section{Miksei Toivo Kärjestä tullut myyttiä?}

Kyetäkseni korostamaan oikeanlaisen elämäntarinan välttämättömyyttä, vertaan viimeiseksi Unto Monosen hahmoa Toivo Kärkeen. Toinen on mielestäni myyttinen hahmo, toinen ei. Kolme ensimmäistä myytiltä vaadittavaa ehtoa näyttäisi toteutuvan Kärjen kohdalta osin jopa Monosta paremmin. Kärjen kaupallinen suosio oli kaiken kaikkiaan aivan toista luokkaa kuin Monosen, ja sinivalkoinen suomalaisuus itsestään selvää. Kuolema tosin tuli vasta seitsemän vuotta sitten. Yksi Kärjeltä kuitenkin puuttuu, ja sen mukana kaikki: dramaattinen elämäntarina. Ei löydy alkoholismia eikä traagista tuhoa.

Suurella yleisöllä on vankka käsitys Monosen melankolisen laululyriikan omaelämänkerrallisuudesta. Tämä käsitys on ollut tärkeä Monosen taiteilijan auran muodostumiselle. Siinä missä Kärki on "säveltäjä", Mononen on "taiteilija". Kärki oli tuotannossaan Monosta paljon optimistisempi, koska Kärki oli sodanajan viihdetaiteilija: kansalle täytyi saada viihdettä. Kärki oli Monosta moninverroin ammattilaismaisempi ja laskelmoivampi, mm. käyttäessään useita aliaksia. Kärki oli Monoselle esikuva, Mononen tavoitteli koko uransa ajan samaa ammattimaisen viihdesäveltäjän statusta kuin Kärjellä, turhaan. On ironista, että tämä epäonnistuminen elinaikanaan on tuonut Monoselle kuoleman jälkeen niin paljon gloriaa. Mielenkiintoista on, että Maarit Niiniluodon toimittamassa omaelämänkerrassaan Kärki yrittää miltei väkisin vääntää syrjäyttämisestään Fazerissa 1980-luvun alussa dramaattista käännekohtaa elämässään: Kärki aavisti, että Mononen, jota tämän eläessä Kärki saattoi nöyryyttää mennen tullen, vetäisi kuitenkin kuoleman jälkeen pidemmän korren.

\section{Lähteet}

Asplund, Anneli 1980. Pelimannimusiikki ja uudet soittimet. Teoksessa Kansanmusiikki, toim. Asplund \& Hako. Suomalaisen Kirjallisuuden Seuran toimituksia 366, Helsinki.

Alasuutari \& Kytömäki 1991. Johdanto teoksessa Nykyajan sadut, joukkoviestinnän kertomukset ja vastaanotto. Gaudeamus \& Yleisradio, Jyväskylä. 
Bahtin, Mihail 1995. Francois Rabelais - keskiajan ja renesanssin nauru. Taifuuni, Helsinki.

Barthes, Roland 1994. Mytologioita. Tammer-Paino Oy, Tampere.

Berger, Arthur Asa 1997. Narratives in Popular Culture, Media, and Everyday Life. Sage Publications, London.

Broms, Henri 1984. Alkukuvien jäljillä. Kulttuurin semiotiikkaa. WSOY, Juva.

Falk, Pasi \& Sulkunen, Pekka 1980. Suomalainen humala valkokankaalla. Sosiologia 4/1980.

Greimas, A. J. 1980. Strukturaalista semantiikkaa. Gaudeamus, Tampere.

Jalkanen, Pekka 1991. Miksi populaarimusiikki on populaaria? Musiikin Suunta $1 / 1991$.

Kinnunen, Aarne 1991. Kertomuksen teoreettista pohdintaa. Teoksessa Nykyajan sadut, joukkoviestinnän kertomukset ja vastaanotto. Gaudeamus \& Yleisradio, Jyväskylä.

Korhonen, Inkeri \& Oksanen, Katja 1997. Kertomuksen semiotiikka. Teoksessa Semioottisen sosiologian näkökulmia, toim. Sulkunen \& Törrönen. Gaudeamus, Tampere.

Kukkonen, Pirjo 1997. Ilon ja surun sointu. Folkloresta poploreen. Yliopistopaino, Helsinki.

Sulkunen, Pekka 1997. Todellisuuden ymmärrettävyys ja diskurssianalyysin rajat. Teoksessa Semioottisen sosiologian näkökulmia, toim. Sulkunen \& Törrönen. Gaudeamus, Tampere.

Suutari, Pekka 1994. Tangon akkulturaatio suomalaiskansallisen iskelmän avainsymboliksi. Musiikin Suunta 3/1994.

Tarasti, Eero 1990. Johdatusta semiotiikkaan. Esseitä taiteen ja kulttuurin merkkijärjestelmistä. Gaudeamus, Helsinki.

Törrönen, Jukka 1997. Sosiologisen tekstianalyysin semioottiset välineet. Lisensiaatintutkimuksen julkaisematon yhteenvetoartikkeli. Helsingin yliopiston valtiotieteellinen tiedekunta, sosiologia. 